\title{
A hepatoprotective Lindera obtusiloba extract suppresses growth and attenuates insulin like growth factor-1 receptor signaling and NF-kappaB activity in human liver cancer cell lines
}

\author{
Christian Freise', Martin Ruehl', Ulrike Erben', Ulf Neumannn ${ }^{2,3}$, Daniel Seehofer ${ }^{2}$, Ki $^{1}$ Young Kim",
} Wolfram Trowitzsch-Kienast ${ }^{5}$, Thorsten Stroh ${ }^{1}$, Martin Zeitz ${ }^{1}$ and Rajan Somasundaram ${ }^{1 *}$

\begin{abstract}
Background: In traditional Chinese and Korean medicine, an aqueous extract derived from wood and bark of the Japanese spice bush Lindera obtusiloba (L.obtusiloba) is applied to treat inflammations and chronic liver diseases including hepatocellular carcinoma. We previously demonstrated anti-fibrotic effects of L.obtusiloba extract in hepatic stellate cells. Thus, we here consequently examine anti-neoplastic effects of L.obtusiloba extract on human hepatocellular carcinoma (HCC) cell lines and the signaling pathways involved.

Methods: Four human HCC cell lines representing diverse stages of differentiation were treated with L.obtusiloba extract, standardized according to its known suppressive effects on proliferation and TGF- $\beta$-expression. Beside measurement of proliferation, invasion and apoptosis, effects on signal transduction and NF- $\kappa \mathrm{B}$-activity were determined.

Results: L.obtusiloba extract inhibited proliferation and induced apoptosis in all HCC cell lines and provoked a reduced basal and IGF-1-induced activation of the IGF-1R signaling cascade and a reduced transcriptional NF- $\kappa$ Bactivity, particularly in the poorly differentiated SK-Hep1 cells. Pointing to anti-angiogenic effects, L.obtusiloba extract attenuated the basal and IGF-1-induced expression of hypoxia inducible factor-1 $\alpha$, vascular endothelial growth factor, peroxisome proliferator-activated receptor- $\gamma$, cyclooxygenase-2 and inducible nitric oxide synthase.

Conclusions: The traditional application of the extract is confirmed by our experimental data. Due to its potential to inhibit critical receptor tyrosine kinases involved in HCC progression via the IGF-1 signaling pathway and NF- $\kappa \mathrm{B}$, the standardized L.obtusiloba extract should be further analysed for its active compounds and explored as (complementary) treatment option for HCC.
\end{abstract}

\section{Background}

Hepatocellular carcinoma (HCC) results from chronic liver disease and is the most common malignancy of the liver [1]. Chronic Hepatitis B or C leading to liver cirrhosis are major risk factors for the development of HCC [2]. Even in developing countries less than $40 \%$ of patients have a chance for cure when the tumor is diagnosed. In more advanced stages there are only reduced

\footnotetext{
* Correspondence: rajan.somasundaram@charite.de

'Department of Gastroenterology, Infectiology and Rheumatology, Charité Universitätsmedizin Berlin, Campus Benjamin Franklin, Hindenburgdamm 30, 12203 Berlin, Germany

Full list of author information is available at the end of the article
}

therapeutic options, since e.g. the use of more aggressive chemotherapeutic approaches is often limited by significant liver dysfunction/cirrhosis. Thus, the median survival in advanced HCC without therapy ranges from 4.2 to 7.9 months or even less [3,4]. Small molecules, targeting tumor angiogenesis, apoptosis or specific signal transduction pathways, have gained growing attention in cancer therapy. The multikinase inhibitor sorafenib is currently the only approved drug for the treatment of HCC, prolonging median survival of advanced HCC from 7.9 to 10.4 months [4]. But side effects and upcoming resistances reveal that monotherapies with

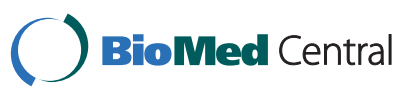

(c) 2011 Freise et al; licensee BioMed Central Ltd. This is an Open Access article distributed under the terms of the Creative Commons Attribution License (http://creativecommons.org/licenses/by/2.0), which permits unrestricted use, distribution, and reproduction in any medium, provided the original work is properly cited. 
the kinase inhibitors alone are not sufficient suggesting the need for combinatory and/or multitargeted therapies [5].

The receptor tyrosine kinase insulin like growth factor-1 receptor (IGF-1R) and its ligands, IGF-1 and IGF2 , are essential for cell growth and development [6] but also in the progression of various types of cancer, including $\mathrm{HCC}$ [7-10]. In addition, IGF-1R signaling protects cells from apoptosis mainly through the PI3K/ Akt and Ras-Raf-MAPK pathways [11,12]. Activation of IGF-1R critically impacts HCC angiogenesis by induced expression of vascular endothelial growth factor (VEGF) and its transcription factor hypoxia inducible factor (HIF)-1 $\alpha$ [13-15]. Inhibition of IGF-1R, e.g by monoclonal antibodies against IGF-1R, has been shown to block tumor growth in vitro and in a xenograft model of HCC and to sensitize cells for anti-tumor treatment, indicating that IGF-1R is a promising antineoplastic target [16-18]. A clinical trial targeting IGF-1R inhibition is currently ongoing in patients with advanced solid tumors. Preliminary data suggest evidence of clinical activity and good tolerance [19].

IGF-1R signaling via the PI-3K/AKT-axis also impacts the nuclear factor-kappaB $(\mathrm{NF}-\kappa \mathrm{B})$, which is not only considered a key factor in inflammation but also regulates angiogenesis and as a major characteristic mediates inhibition of apoptosis [20]. NF- $\kappa \mathrm{B}$ is spontaneously activated in HCC cells $[21,22]$ and induces expression of cyclooxygenase-2 (COX-2) or inducible nitric oxide synthase (iNOS) which support cell survival and might contribute to the resistance against exogenously induced tumor cell apoptosis [23,24].

Traditionally, Oriental medicine makes use of compositions from or mixtures of different plants to prevent or to treat cancer and liver diseases $[25,26]$. Novel multitargeted therapeutics including natural compounds such as epigallocatechin-3-gallate from green tea have gained growing attention [27].

In traditional Chinese and Korean medicine preparations from Lindera obtusiloba (L.obtusiloba) comprise a good physiological compatibility and are applied to treat inflammations and to improve blood circulation [28]. Especially in Korean medicine an extract of L.obtusiloba is used for a long time for the treatment of chronic liver diseases which includes treatment of HCC the endstage of chronic liver disease (personal communication, Prof. Ki Young Kim, Wonkwang University, Korea).

Bioactive components from the leaves of L.obtusiloba described so far exert cytotoxicity against tumors as shown with human cancer cell lines from lung (A549), ovarian cancer (SK-OV-3), skin (SK-MEL-2), the central nervous system (XF498) or colon (HCT15) with halfmaximum inhibitory concentration $\left(\mathrm{IC}_{50}\right)$ values ranging from 3-20 $\mu \mathrm{g} / \mathrm{ml}$ of the respective compounds [29,30]. We previously found an aqueous extract from wood and bark of L.obtusiloba to suppress profibrotic stimuli, exerting anti-oxidative activity, reduction of the expression of pro-fibrotic marker proteins and inhibition of matrix-metalloproteinases in hepatic stellate cells [31]. In addition, this extract displayed anti-inflammatory and anti-adipogenic activity in 3T3-L1 preadipocytes [32].

However, experimental data from in vitro or in vivo studies on anti-neoplastic effects of L.obtusiloba extracts in human HCC as complication of chronic liver disease were not reported so far. We here used well established $\mathrm{HCC}$ cell lines that represent diverse stages of differentiation and different degrees of invasiveness to examine direct anti-neoplastic effects of L.obtusiloba extract, standardized to its antiproliferative and anti-fibrotic effects, on tumor cells and to get insights into signaling pathways involved. With a clear focus on aspects affecting angiogenesis and tumor cell invasion, we aimed to understand mechanisms of action of L.obtusiloba extract.

\section{Methods}

\section{Materials and reagents}

Tissue culture plates and polystyrene microtiter for ELISA as well as for fluorimetric analysis were from Nunc (Roskilde, Denmark) and Dynex (Chantilly, VA), respectively. If not stated otherwise, all reagents were purchased from Merck (Darmstadt, Germany) or SigmaAldrich (Deisenhofen, Germany) and were of the highest purity available. Cell culture media and solutions were purchased from Invitrogen (Karlsruhe, Germany) or Biochrom (Berlin, Germany).

\section{Preparation and standardization of L.obtusiloba extract}

Freeze-dried extracts of L.obtusiloba were obtained as described previously [31]. To obtain stock solutions, 10 mg powder was redissolved in $10 \mathrm{ml}$ sterile phosphatebuffered saline (PBS) at $60^{\circ} \mathrm{C}$ for $30 \mathrm{~min}$. Aliquots were stored at $-20^{\circ} \mathrm{C}$. Freshly prepared working solutions of $L$. obtusiloba extract were routinely standardized according to their anti-fibrotic and anti-inflammatory activity as previously described [31,32]. Briefly, $100 \mu \mathrm{g} / \mathrm{ml} \mathrm{L.obtusi-}$ loba extract had to reduce proliferation of 3T3-L1 preadipoctyes by $45 \%$ and to suppress the autocrine stimulation of TGF- $\beta$ expression of hepatic stellate cells by $50 \%$ before to be used in the assays with HCC cells.

\section{Cell culture}

The human HCC cell lines HepG2 (ATCC HV-8062), Hep3B (ATCC HV-8064), Huh-7 (JCRB 0403; Tokio, Japan) and SK-Hep1 (ATCC HTB-52) cells (Fuchs et al., 2008) were cultured in a humidified atmosphere at $37^{\circ} \mathrm{C}$ and $5 \% \mathrm{CO}_{2}$. Standard culture medium consisted of DMEM with $862 \mathrm{mg} / \mathrm{l} \mathrm{L}$-alanyl-L-glutamine, $4.5 \mathrm{~g} / \mathrm{l} \mathrm{glu-}$ cose, $50 \mu \mathrm{g} / \mathrm{ml}$ streptomycin, 50 units $/ \mathrm{ml}$ penicillin, 
$50 \mu \mathrm{g} / \mathrm{ml}$ L-ascorbic acid, supplemented with $10 \%$ heatinactivated fetal bovine serum (FBS). Cell layers were detached with $0.05 \%$ trypsin/0.02\% EDTA solution. Cell morphology in culture was directly examined by inverse phase contrast microscopy (Zeiss, Oberkochen, Germany).

\section{HCC cell proliferation}

HCC cells $\left(5 \times 10^{3}\right)$ were seeded into 96-well tissue culture plates in $100 \mu \mathrm{l}$ standard culture medium. After 24 $\mathrm{h}$, cells were cell cycle synchronized in $100 \mu$ l culture medium containing $0.2 \%$ FBS for additional $24 \mathrm{~h}$. Cultures were treated with up to $200 \mu \mathrm{g} / \mathrm{ml} \mathrm{L.obtusiloba}$ extract as indicated for $20 \mathrm{~h}$. Proliferation was determined by adding $0.5 \mu \mathrm{Ci} /$ well $\left[{ }^{3} \mathrm{H}\right.$ ]-thymidine (GE Healthcare, Munich, Germany) for $4 \mathrm{~h}$. Cells were fixed with $10 \%$ trichloro acetic acid and the DNA was solubilized with $200 \mathrm{mM} \mathrm{NaOH}$, neutralized with an equal volume of $800 \mathrm{mM} \mathrm{HCl}$ and transferred to glass filter pads. Radioactive decay was monitored by liquid $\beta$-scintillation counting within $1 \mathrm{~min}$ (LKB Wallac Turku, Finland).

\section{Cell invasion assays}

$50 \mu \mathrm{l}$ of $3 \mathrm{mg} / \mathrm{ml}$ Matrigel ${ }^{\mathrm{TM}}$ (BD Biosciences, Heidelberg, Germany) diluted in ice cold, serum free DMEM were used to coat the upper compartments of 24-well transwell inserts (BD Biosciences; pore size $8 \mu \mathrm{m}$ ) for $16 \mathrm{~h}$ at $37^{\circ} \mathrm{C} .2 \times 10^{5}$ cells diluted in $300 \mu \mathrm{l}$ serum free medium were seeded into the upper compartments and L.obtusiloba extract was added at a final concentration of $100 \mu \mathrm{g} / \mathrm{ml}$. DMEM containing 10\% FBS as stimulating agent was added to the lower compartment and the plates were incubated for up to $24 \mathrm{~h}$ at $37^{\circ} \mathrm{C}$ in a humidified atmosphere with $5 \% \mathrm{CO}_{2}$. Cells that remained in the upper compartment were gently removed with a cotton swab. The inserts were then washed with PBS and invaded cells on the lower surface of the insert were fixed for $20 \mathrm{~min}$ with $2 \%$ glutaraldehyde in PBS and stained using $0.1 \%$ crystal violet in water. The stained cells on each insert were visualized by light microscopy and manually counted in three independent spots per insert.

\section{Apoptosis by caspase $3 / 7$ activity}

Apoptosis was quantified fluorimetrically from caspase$3 / 7$ activity. In brief, $2 \times 10^{5} \mathrm{HCC}$ cells in standard culture medium were seeded into 24-well tissue culture plates. Confluent cell layers were thoroughly washed with DMEM and subsequently incubated with culture medium containing $0.2 \%$ FBS for $24 \mathrm{~h}$. Cells were then treated for another $24 \mathrm{~h}$ in the presence of $100 \mu \mathrm{g} / \mathrm{ml} \mathrm{L}$. obtusiloba extract or $100 \mathrm{nM}$ staurosporine and $0.2 \%$ FBS. Apoptosis was determined using the SensoLyte ${ }^{\mathrm{TM}}$ Homogenous AFC Caspase-3/7 Assay Kit (AnaSpec, San
Jose, CA) according to the manufactures instructions. Briefly, cells were lysed in $200 \mu \mathrm{l}$ lysis buffer for $1 \mathrm{~h}$ at $4^{\circ} \mathrm{C}$. The clear supernatant obtained after centrifugation at $2,500 \times \mathrm{g}$ for $30 \mathrm{~min}$ was stored at $-80^{\circ} \mathrm{C}$ until measurement. Caspase 3/7-mediated conversion of the substrate N-acetyl-Asp-Glu-Val-Asp-7 amino-4 trifluoromethyl coumarin was monitored fluorometrically using a Spectramax Gemini EM microplate reader ( $\lambda$ ex: $380 \mathrm{~nm}, \lambda \mathrm{em}$ : 500 nm; Molecular Devices, Sunnyvale, CA).

\section{Western-blot}

HCC cells cultured in 6-well tissue culture plates with $125 \mathrm{ng} / \mathrm{ml}$ human recombinant IGF-1 (Biomol, Hamburg, Germany), $100 \mu \mathrm{g} / \mathrm{ml}$ L.obtusiloba extract and a combination of both for $48 \mathrm{~h}$ were rinsed with ice-cold PBS and lysed with a lysis-buffer containing $50 \mathrm{mM}$ Tris- $\mathrm{HCl} \mathrm{pH} 7.4,2.25 \mathrm{M}$ urea, 1.4\% sodium dodecyl sulfate, $100 \mathrm{mM}$ dithiothreitol, $2 \mathrm{mM} \mathrm{NaVO}_{3}, 5 \mathrm{mM} \mathrm{NaF}$, and per $10 \mathrm{ml}$ buffer one tablet of Complete Mini Protease Inhibitor cocktail (Roche, Penzberg, Germany). Aliquots of $333 \mu \mathrm{l}$ lysate were transferred to $0.5 \mathrm{ml}$ reaction tubes and frozen at $80^{\circ} \mathrm{C}$. Protein content was determined using the Nano Orange Protein Assay Kit (Molecular Devices) according to the manufactures instructions. From each cell lysate, $25 \mu \mathrm{g}$ protein per lane were separated by SDS-PAGE and transferred to nitrocellulose membranes (Bio-Rad, Munich, Germany) using a tank blot apparatus (Hoefer, Holliston, MA). Membranes blocked for $1 \mathrm{~h}$ with $5 \%$ skim milk powder in a buffer containing $10 \mathrm{mM}$ Tris, $154 \mathrm{mM} \mathrm{NaCl}, 0.1 \%$ Tween 20 were incubated over night at $4{ }^{\circ} \mathrm{C}$ with the following specific primary antibodies with the dilution given: Akt (1:1,250), COX-2 (1:1,000), Erk1/2 (1:1,000), iNOS $(1: 1,500)$, pAkt $(1: 1,250)$, pErk1/2 (1:1,250), Stat3 (1:1,250; Cell Signaling, Beverly, MA), $\beta$-Actin (1:10,000), HIF-1 $\alpha$ (1:2,000; Novus Biologicals, Littleton, CO, USA), IGF-1R (1:1,250), pIGF-1R (1:1,250; Imgenex, San Diego, CA) and PPAR $\gamma(1: 2,000), \operatorname{pStat} 3(1: 1,250)$, VEGF (1:800; Santa Cruz, Santa Cruz, CA). After washing, membranes were incubated for $1 \mathrm{~h}$ with rabbit or mouse immunoglobulin G-specific horseradish peroxidase-labeled secondary antibodies (1:2,500; Dako, Hamburg, Germany). Bands were detected by enhanced chemiluminescence (GE Healthcare) using the Luminescent Image Analyser LAS-4000 (Fujifilm, Düsseldorf, Germany). Band intensities were quantified using Image $J$ and normalized to the $\beta$-actin loading control.

\section{Transient transfection of HCC cells}

Transfection of the cells was performed using the electroporation method and a NF- $\kappa \mathrm{B}$-luciferase reporter plasmid as described by Stroh et al. [33,34]. Detached cells $\left(2 \times 10^{5}\right)$ were resuspended in $100 \mu$ l electroporation buffer containing $90 \mathrm{mM}$ phosphate buffer $\mathrm{pH}$ 7.2, 
$10 \mathrm{mM} \mathrm{MgCl} 2$, and $50 \mathrm{mM}$ glucose before $4 \mu \mathrm{g}$ of the NF- $\kappa$ B-luciferase reporter plasmid pNF- $\kappa$ B-TA-Luc (Clontech, Mountain View, CA) were added. In an electroporation cuvette with a gap of $2 \mathrm{~mm}$ (Biozym, Hessisch Oldendorf, Germany), cells were subjected to single square pulses of $400 \mathrm{~V}$ for $400 \mu$ s (HepG2, Hep3B and Huh-7) or $600 \mathrm{~V}$ for $400 \mu$ s (SK-Hep1), allowed to rest for $1 \mathrm{~min}$, and transferred into prewarmed standard culture medium. A total of $1 \times 10^{5}$ transfected cells in $1 \mathrm{ml}$ culture medium were seeded into a 24-well plate. Cell viability as determined by Calcein AM staining [32] was about $85 \%$ in conjunction with a cell transfection efficacy of $\sim 75 \%$.

\section{Assessment of NF- $\kappa$ B activation by luciferase assay}

Twenty hours after transfection with the NF- $\kappa$ B-luciferase reporter plasmid [33] cells were treated with $10 \mu \mathrm{g} / \mathrm{ml}$ recombinant human TNF $\alpha$ (Peprotech, Hamburg, Germany), $100 \mu \mathrm{g} / \mathrm{ml}$ L.obtusiloba extract, a combination of both and $15 \mathrm{nM}$ of the NF- $\kappa \mathrm{B}$ inhibitor 17Dimethylamino-ethylamino-17-demethoxygeldanamycin (17-DMAG, InvivoGen, San Diego, CA). Cells were incubated for $24 \mathrm{~h}$, washed twice with PBS, and lysed in $80 \mu \mathrm{l}$ of reporter lysis buffer (Promega, Mannheim, Germany). Protein concentrations were determined using the Nano Orange Protein Assay Kit. Samples $(20 \mu \mathrm{l})$ were transferred into a white 96 well plate before $60 \mu \mathrm{l}$ of luciferase substrate were added and mixed for $5 \mathrm{~s}$. Luciferase activity was measured for $0.5 \mathrm{~s}$ using a Mithras LB 940 luminescence reader (Berthold Technologies, Bad Wildbad, Germany). NF- $\kappa$ B activity was estimated as relative luminescence units (RLU) corresponding to equal protein amounts.

\section{Statistical Analysis}

One way ANOVA/Tukey Tests were performed using SigmaStat for Windows (version 2.03; Systat, San Jose, CA). $\mathrm{P}<0.05$ was considered significantly different.

\section{Results}

\section{L.obtusiloba extract reduces proliferation, induces apoptosis and blocks invasion of HCC cells}

Effects of L.obtusiloba extract on the proliferation of human HCC cells were tested in cell-cycle synchronized cell lines. To define effective dose ranges, HCC cells in culture were treated with up to $200 \mu \mathrm{g} / \mathrm{ml}$ L.obtusiloba extract (Figure 1A). The range of concentration of L.obtusiloba extract and the experimental protocols were adapted from preceding studies dealing with the extract [31,32].

L.obtusiloba extract reduced the proliferation of all four human HCC cell lines in a dose-dependent manner. The $\mathrm{IC}_{50}$ values for the inhibition of the de novo DNA synthesis were approximately $100 \mu \mathrm{g} / \mathrm{ml}$ L.obtusiloba extract for all HCC cell lines. This concentration was used in all subsequent experiments. Induction of apoptosis due to exposure of cells with L.obtusiloba extract was determined by the enzymatic activity of pro-apoptotic caspase-3/-7 (Figure 1B). As shown for the apoptosis inducer and kinase inhibitor staurosporine used as control, all cell lines were highly susceptible to induction of apoptosis by L.obtusiloba extract as shown by 2.2- to 20 -fold enhanced caspase activity. In the differentiated HCC cell lines HepG2, Hep3B and Huh-7, this effect of L.obtusiloba extract did not exceed $60 \%$ of the effect of $100 \mathrm{nM}$ staurosporine. In contrast, L.obtusiloba extract provoked a caspase activity that corresponded to $\sim 80 \%$ of apoptosis induced by staurosporine in the poorly differentiated SKHep1 cells $(P<0.001)$. Since their migratory potential mainly defines their aggressiveness, $100 \mathrm{mg} / \mathrm{ml} \mathrm{L.obtusi-}$ loba extract was applied to HCC cells in matrigel invasion assays. Again, while L.obtusiloba extract only slightly attenuated the invasion of HepG2, Huh-7 $(\mathrm{P}<0.05)$ and Hep3B cells through a reconstituted basement membrane, it led to a stronger reduction of invasion in SK-Hep1 cells by $55 \%(\mathrm{P}<0.01)$ (Figure $1 \mathrm{C})$. As for direct effects of L.obtusiloba extract on tumor cells, it diminished the invasive potential of HCC cell lines and was most effective on cells displaying a highly aggressive phenotype.

\section{L.obtusiloba extract reduces basal and IGF-1-induced protein expression of VEGF and its transcription factor HIF-1 $\alpha$}

HCC represents a highly vascularized tumor entity and the tumor cells contribute to that process by production of proteins regulating angiogenesis. Thus, we next investigated whether L.obtusiloba extract impacts the expression of VEGF and HIF-1 $\alpha$ in HCC cell lines. Linking Huh-7 to SK-Hep1 cells, stimulation with exogenous IGF-1 enhanced basal expression of VEGF by 1.4- or 3.3-fold, while in HepG2 and Hep3B no effects of IGF-1 were observed (Table 1). L.obtusiloba extract alone reduced VEGF expression in all four cell lines but strongest in Huh-7 cells. In combination with IGF-1, L.obtusiloba extract did not affect the IGF-1-induced VEGF expression in HepG2 cells, but in Hep3B, Huh-7 and SK-Hep1. The IGF-1-induced enhancement of HIF $1 \alpha$ expression was most prominent in differentiated HepG2 cells (3.6-fold) and intermediate in Hep3B (1.5-fold) and SK-Hep1 cells (1.3-fold). In Huh-7 cells no significant IGF-1-mediated effects on HIF $1 \alpha$ expression were observed. Similar to VEGF, L.obtusiloba extract distinctly reduced basal and IGF-1-induced HIF-1 $\alpha$ expression in each of the HCC cell lines to comparable individual levels that were independent of the presence of IGF-1. These findings on VEGF and HIF- $1 \alpha$ pointed to a strong anti-angiogenic potential of L.obtusiloba extract. Consequently, we studied the 

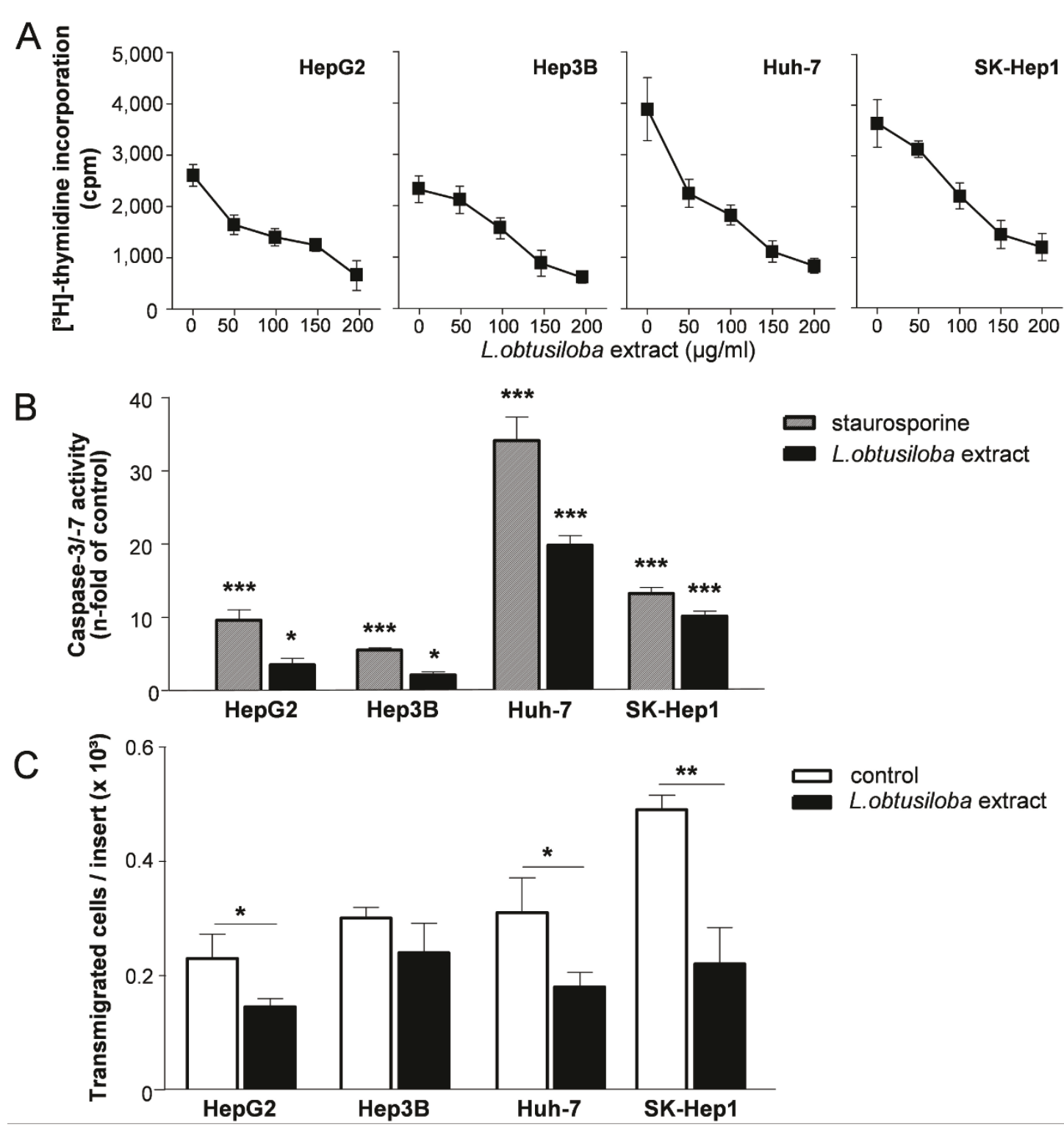

Figure 1 Proliferation, apoptosis and invasion of HCC cell lines treated with L.obtusiloba extract. (A) Cell cycle synchronized HepG2, Hep3B, Huh 7 and SK-Hep1 cells were treated with up to $200 \mu \mathrm{g} / \mathrm{ml}$ L.obtusiloba extract for $24 \mathrm{~h}$. Cultures without L.obtusiloba extract served as controls. Proliferation was determined by $\left[^{3} \mathrm{H}\right]$-thymidine incorporation within the last $4 \mathrm{~h}$ of the culture. Mean values \pm SD of three parallel measurements. (B) HCC cells were incubated with $100 \mu \mathrm{g} / \mathrm{ml}$ L.obtusiloba extract for $24 \mathrm{~h}$. Cultures without additives or with $100 \mathrm{nM}$ staurosporine served as negative or positive controls, respectively. Enzymatic activities of caspase-3/7 were determined from cell lysates by fluorogenic substrate conversion. Shown are the mean values \pm SD of four parallel measurements. (C) HCC cells were allowed to invade membranes coated with basement collagen in the absence or presence of $100 \mu \mathrm{g} / \mathrm{ml}$ L.obtusiloba extract. After 24 h, transmigrated cells were stained with crystal violet and numbers were counted. Shown are the mean values \pm SD of three independent experiments with four parallel measurements. ${ }^{*} P<0.05$, ${ }^{* *} P<0.01,{ }^{* *} P<0.001$.

impact of L.obtusiloba extract on the expression of other proteins crucial in neo-angiogenesis.

\section{L.obtusiloba extract decreases the protein expression of PPAR $\gamma$, COX-2 and iNOS}

The expression of the nuclear transcription factor PPAR $\gamma$ and its target genes COX-2 and iNOS are implicated in hepatocarcinogenesis and in the formation of enhanced microvessel density in HCC tissues. Effects of L.obtusiloba extract on the expression of PPAR $\gamma$, COX-2 and iNOS were examined at protein level (Table 2). The expression of PPAR $\gamma$ in all four HCC cell lines was enhanced after stimulation with IGF-1. L.obtusiloba extract reduced both, basal and IGF-1-induced PPAR $\gamma$ 
Table 1 Expression of VEGF and HIF-1 $\alpha$ in human HCC cell lines

\begin{tabular}{lcccccc}
\hline & \multicolumn{3}{c}{ VEGF expression } & \multicolumn{2}{c}{ HIF-1 $\alpha$ expression } \\
\cline { 2 - 7 } & IGF-1 & L.obtusiloba extract & IGF-1 and L.obtusiloba extract & IGF-1 & L.obtusiloba extract & IGF-1 and L.obtusiloba extract \\
\hline HepG2 & $1.02 \pm 0.03$ & $0.75 \pm 0.10^{*}$ & $0.93 \pm 0.06$ & $3.58 \pm 0.26^{*}$ & $0.72 \pm 0.07^{*}$ & $0.82 \pm 0.11^{\#}$ \\
Hep3B & $0.82 \pm 0.18$ & $0.67 \pm 0.09^{*}$ & $0.54 \pm 0.10^{* \#}$ & $1.52 \pm 0.21^{*}$ & $0.62 \pm 0.11^{*}$ & $0.63 \pm 0.07^{*}$, \\
Huh-7 & $1.38 \pm 0.05^{*}$ & $0.28 \pm 0.10^{*}$ & $0.47 \pm 0.08^{* \#}$ & $0.89 \pm 0.12$ & $0.14 \pm 0.04^{*}$ & $0.05 \pm 0.03^{*},{ }^{*}$ \\
SK-Hep1 & $3.28 \pm 0.24^{*}$ & $0.93 \pm 0.10$ & $0.83 \pm 0.09^{\#}$ & $1.28 \pm 0.13^{*}$ & $0.67 \pm 0.09^{*}$ & $0.68 \pm 0.12^{*},{ }^{*}$ \\
\hline
\end{tabular}

Whole cell lysates from cells treated with $100 \mu \mathrm{g} / \mathrm{ml}$ L.obtusiloba extract, $125 \mathrm{ng} / \mathrm{ml}$ human IGF-1 or a combination of both for $48 \mathrm{~h}$ and from untreated cells as control were analyzed by western-blot specific for VEGF and HIF-1 $\alpha$. $\beta$-Actin was stained for equal loading control and specific band intensities were normalized to $\beta$-actin. VEGF and HIF-1 $\alpha$ protein expression levels were calculated in relation to the respective untreated cells. Mean values \pm SD from three independent experiments. ${ }^{*} \mathrm{P}<0.05$ compared to the untreated control, ${ }^{\#} \mathrm{P}<0.05$ compared to IGF-1-treated cells.

expression with the same pattern as HIF-1 $\alpha$ (Table 1). COX-2 was not detected in HepG2 and Huh-7 cells (Table 2). On the other hand, Hep3B and SK-Hep1 showed a high IGF-1-induced expression of COX-2 by 2.3- and 3.2-fold, respectively and with L.obtusiloba extract a reduction of both, the basal and the IGF-1induced COX-2 expression. Hep3B and Huh 7 cells showed no expression of iNOS. In HepG2 and SK-Hep1 cells the basal expression of iNOS was enhanced by IGF1 by 1.2 - and 1.9 -fold, respectively. L.obtusiloba extract reduced the basal and the IGF-1-induced iNOS expression of both cell lines by $\sim 80 \%$.

Taken together and complementing the results from the preceding experiments, these data suggest direct effects of L.obtusiloba extract on the angiogenic program of HCC cells via decreased expression of PPAR $\gamma$ and its target genes COX-2 and iNOS thus contributing to dampened growth and motility of HCC cells.

L.obtusiloba extract blocks expression of VEGF and HIF-1 $\alpha$ via attenuated activation of IGF $1 \mathrm{R}$ downstream targets The IGF-1/IGF-1R axis plays an important role in angiogenesis and therefore the development of HCC. To investigate signaling pathways involved, western-blots specific for (p)IGF-1R and the activation states of its target proteins were focused on Hep3B as one out of the three less invasive HCC cells (compare Figure 1C) and the more aggressive SK-Hep1 cells. In both cell lines
$100 \mu \mathrm{g} / \mathrm{ml}$ exogenous IGF-1 increased the phosphorylation state of the IGF-1R (Figure 2, Table 3). This IGF-1mediated activation of the IGF-1R was strongly reduced in the presence of L.obtusiloba extract; by half in the Hep3B and to about a quarter in SK-Hep1 cells. As for the downstream signaling molecules Akt, Stat3 and Erk, L.obtusiloba extract did not alter basal phosphorylation. IGF-1 induced phosphorylation of Akt, Stat3 and Erk were tested in both cell lines. Increased pAkt levels that were at least partially abrogated by L.obtusiloba extract were found to be the most prominent effect. Treatment with L.obtusiloba extract in combination with IGF-1 markedly decreased the levels of pAkt, pStat3 and pErk in Hep3B and SK-Hep1 cells.

These findings that L.obtusiloba extract decreased the basal phosphorylation of Akt, Stat3 and Erk in Hep3B cells as well as in poorly differentiated SK-Hep1 cells as a result of reduced stimulatory effects of IGF-1 on its receptor explains the inhibition of growth and motility and the induction of apoptosis in HCC cells.

\section{L.obtusiloba extract decreases transcriptional activity of $\mathrm{NF}-\kappa \mathrm{B}$}

$\mathrm{NF}-\kappa \mathrm{B}$ is a key regulator of crucial pro-inflammatory cytokines during carcinogenesis and promotes cell survival and angiogenesis. Since L.obtusiloba extract induces apoptosis (Figure 1B) and displays anti-inflammatory activity [32], we assessed whether the extract decreases

Table 2 Expression of PPAR $\gamma$, COX-2 and iNOS in human HCC cell lines

\begin{tabular}{|c|c|c|c|c|c|c|c|c|c|}
\hline & \multicolumn{3}{|c|}{ PPAR $\gamma$ expression } & \multicolumn{3}{|c|}{ COX-2 expression } & \multicolumn{3}{|c|}{ iNOS expression } \\
\hline & IGF-1 & $\begin{array}{c}L . \\
\text { obtusiloba } \\
\text { extract }\end{array}$ & $\begin{array}{l}\text { IGF-1 and } L . \\
\text { obtusiloba } \\
\text { extract }\end{array}$ & IGF-1 & $\begin{array}{c}\text { L.obtusiloba } \\
\text { extract }\end{array}$ & $\begin{array}{l}\text { IGF-1 and } L . \\
\text { obtusiloba } \\
\text { extract }\end{array}$ & IGF-1 & $\begin{array}{c}L . \\
\text { obtusiloba } \\
\text { extract }\end{array}$ & $\begin{array}{c}\text { IGF-1 and } L . \\
\text { obtusiloba } \\
\text { extract }\end{array}$ \\
\hline HepG2 & $4.31 \pm 0.51^{*}$ & $0.76 \pm 0.14$ & $1.15 \pm 0.09^{\#}$ & n.d. & n.d. & n.d. & $1.17 \pm 0.07$ & $0.21 \pm 0.14^{*}$ & $0.21 \pm 0.09^{*}, \#$ \\
\hline Нер3В & $1.33 \pm 0.12^{*}$ & $0.84 \pm 0.09$ & $0.81 \pm 0.05^{\#}$ & $2.28 \pm 0.19^{*}$ & $0.77 \pm 0.08^{*}$ & $1.09 \pm 0.04^{*}$ & n.d. & n.d. & n.d. \\
\hline Huh-7 & $1.17 \pm 0.05$ & $0.21 \pm 0.10^{*}$ & $0.31 \pm 0.12^{*}$ & n.d. & n.d. & n.d. & n.d. & n.d. & n.d. \\
\hline $\begin{array}{l}\text { SK- } \\
\text { Hep1 }\end{array}$ & $1.43 \pm 0.11^{*}$ & $0.75 \pm 0.09^{*}$ & $0.89 \pm 0.07^{\#}$ & $3.21 \pm 0.34^{*}$ & $0.80 \pm 0.07^{*}$ & $0.82 \pm 0.09^{\#}$ & $1.87 \pm 0.12^{*}$ & $0.27 \pm 0.12^{*}$ & $0.35 \pm 0.06^{*}$ \\
\hline
\end{tabular}

Cell lysates of HCC cell lines as described for Table 1, were subjected to specific western-blots for PPAR $\gamma$, COX 2 and iNOS and for $\beta$ actin as equal loading control. Densitometry of specific band intensity was normalized to $\beta$-actin expression. Mean values \pm SD from three independent experiments. PPAR $\gamma$, COX- 2 and iNOS protein expression levels were calculated in relation to the respective untreated cells. Mean values \pm SD from three independent experiments. ${ }^{*} P<0.05$ compared to the untreated control, ${ }^{\#} \mathrm{P}<0.05$ compared to IGF-1-treated cells, n.d. - not detected. 


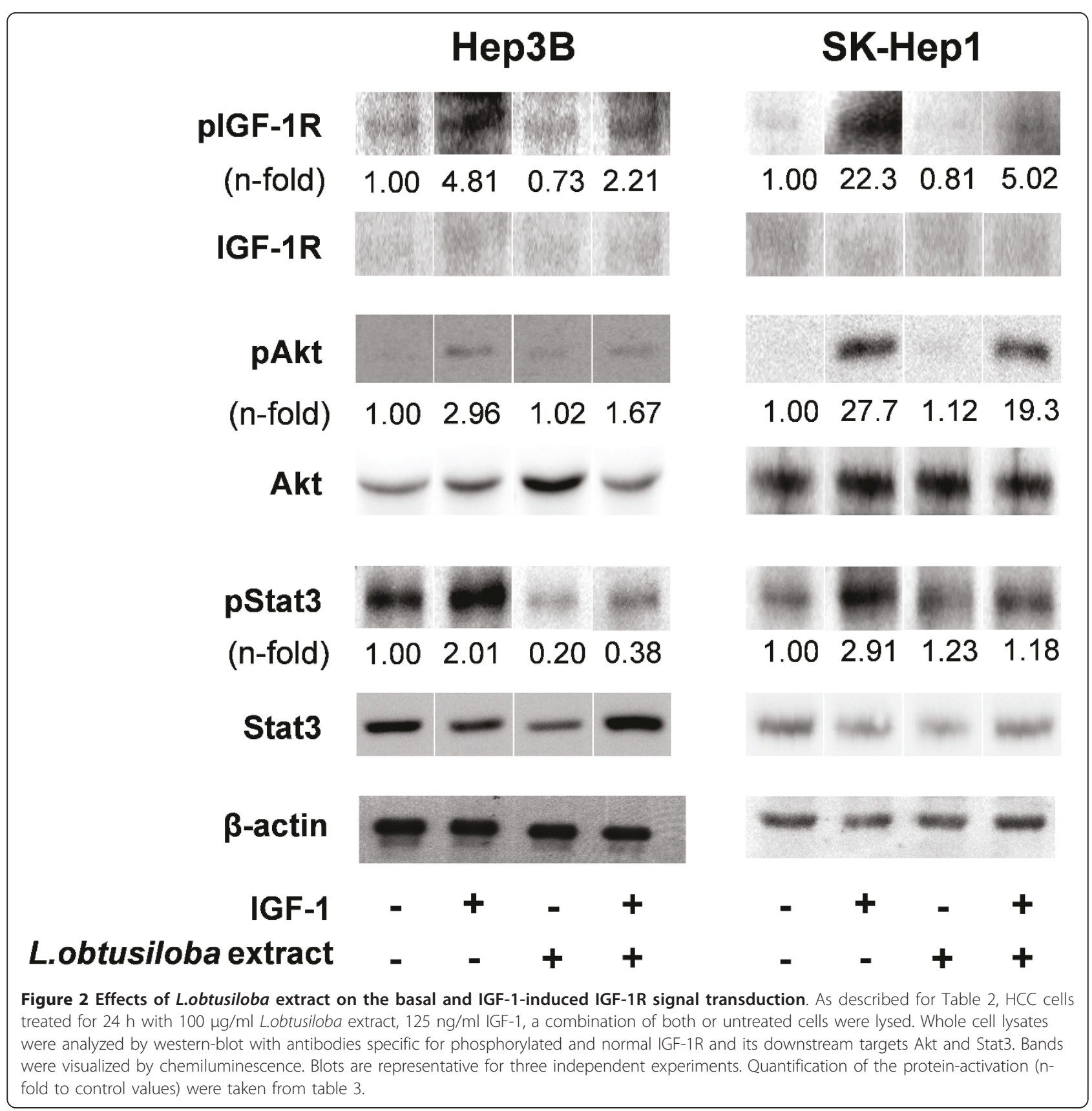

the activity of NF- $\kappa \mathrm{B}$ in $\mathrm{HCC}$ cells (Figure 3 ). All four $\mathrm{HCC}$ cell lines transfected for transient constitutive expression of NF- $\kappa \mathrm{B}$ exhibited high levels of basal NF$\kappa \mathrm{B}$ transcriptional activity of about $160260 \mathrm{RLU}$. This activity was not significantly increased by addition of TNF $\alpha$. In all cell lines, treatment of transfected cells with the specific NF- $\kappa$ B-inhibitor $17-D M A G$ reduced the activity to $<10 \%$ of the basal level thus approving the function of the experimental system (data not shown). Except for HepG2 cells, L.obtusiloba extract attenuated the transcriptional activity of NF- $\kappa \mathrm{B}$ to $75 \%$
$(\mathrm{P}<0.05)$ of the basal level in Huh-7 and to $~ 65 \%$ ( $\mathrm{P}<$ $0.001)$ in Hep3B cells while in the poorly differentiated SK-Hep1 cells the high basal transcriptional activity of $\mathrm{NF}-\kappa \mathrm{B}$ was reduced to $50 \%(\mathrm{P}<0.001)$. These results at the level of regulation clearly strengthen our conclusion that L.obtusiloba extract directly impairs the survival and the angiogenic program in HCC cells.

\section{Discussion}

In the present study with human HCC cell lines we provide evidence that a well standardized aqueous extract 
Table 3 Effects of L.obtusiloba extract on basal and IGF-1-induced signal transduction via IGF-1R

\begin{tabular}{lcccccc}
\hline & \multicolumn{2}{c}{ Hep3B } & \multicolumn{2}{c}{ SK-Hep1 } \\
\cline { 2 - 7 } & IGF-1 & $\begin{array}{c}\text { L.obtusiloba } \\
\text { extract }\end{array}$ & $\begin{array}{c}\text { IGF-1 and L.obtusiloba } \\
\text { extract }\end{array}$ & IGF-1 & $\begin{array}{c}\text { L.obtusiloba } \\
\text { extract }\end{array}$ & $\begin{array}{c}\text { IGF-1 and L.obtusiloba } \\
\text { extract }\end{array}$ \\
\hline plGF-1R & $4.81 \pm 0.40^{*}$ & $0.73 \pm 0.08^{*}$ & $2.21 \pm 0.31^{*} ; \#$ & $22.3 \pm 1.98^{*}$ & $0.81 \pm 0.07$ & $5.02 \pm 0.60^{*} ; \#$ \\
pAkt & $2.96 \pm 0.25^{*}$ & $1.02 \pm 0.10$ & $1.67 \pm 0.19^{*} ; \#$ & $27.7 \pm 2.84^{*}$ & $1.12 \pm 0.09$ & $19.3 \pm 1.45^{*} ; \#$ \\
pStat3 & $2.01 \pm 0.18^{*}$ & $0.20 \pm 0.07^{*}$ & $0.38 \pm 0.21^{*} ;$ & $2.91 \pm 0.22^{*}$ & $1.23 \pm 0.20$ & $1.18 \pm 0.19 \#$ \\
pErk2 & $1.32 \pm 0.14^{*}$ & $0.13 \pm 0.03^{*}$ & $0.57 \pm 0.07^{*} ; \#$ & $2.81 \pm 0.32^{*}$ & $1.01 \pm 0.10$ & $1.82 \pm 0.17^{*} ; \#$ \\
\hline
\end{tabular}

HCC cells were treated with $100 \mu \mathrm{g} / \mathrm{ml}$ L.obtusiloba extract, $125 \mathrm{ng} / \mathrm{ml} \mathrm{IGF} \mathrm{1,} \mathrm{a} \mathrm{combination} \mathrm{of} \mathrm{both} \mathrm{or} \mathrm{remained} \mathrm{untreated} \mathrm{for} 24 \mathrm{~h}$. Phosphorylation of IGF-1R and its downstream targets Akt, Stat3 and Erk were studied in whole cell lysates by specific western-blot analysis as shown in representative blots in Fig. 3.

Activation of the proteins was determined from densitometric assessment in comparison to total expression levels of the respective non-phosphorylated protein. Mean values \pm SD in relation to untreated cells from three independent experiments. ${ }^{*} \mathrm{P}<0.05$ compared to the untreated control, ${ }^{\#} \mathrm{P}<0.05$ compared to IGF1 -treated cells.

from wood and bark of L.obtusiloba exerts direct and non-direct anti-neoplastic effects via attenuated IGF-1Rand NF- $\kappa \mathrm{B}$-signaling.

Initially, we examined the effects of a standardized active extract of L.obtusiloba on the proliferation of well characterized human HCC cell lines with poorly differentiated SK-Hep1 considered more aggressive than the other three used. L.obtusiloba extract blocked the growth of the HCC cells in a dose dependent manner with a physiologically relevant $\mathrm{IC}_{50}$ of $\sim 100 \mu \mathrm{g} / \mathrm{ml}$ (Figure 1A) [31,32]. In addition, L.obtusiloba extract inhibited tumor cell invasion (Figure 1C). Here, SK-Hep1 cells rather than the well differentiated HepG2, Hep3B and Huh-7 cells were more sensitive to L.obtusiloba extract. Thus, in conjunction with the induction of apoptosis in all four cell lines (Figure 1B), L.obtusiloba extract exerts three primary prerequisites for the treatment of cancer $[35,36]$.

Aberrant growth and apoptosis regulation in carcinogenesis is mediated by growth factor receptors such as
IGF-1R which therefore represents an attractive therapeutic target $[8,37]$ and all of the four cell lines investigated are known to express the IGF-1R [38]. Since HCC is characterized by strong neo-angiogenesis [39] with VEGF as its main mediator we investigated the upstream IGF-1/IGF-1R signal transduction and the expression of VEGF via induction of HIF-1 $\alpha$ [13]. $L$. obtusiloba extract blocked the basal and IGF-1-induced protein expression of HIF- $1 \alpha$ and VEGF accompanied by decreased phosphorylation of Akt, Stat3 and Erk. (Figure 2, Tables 1, 2, 3). Since a forced activation of Akt, Stat 3 and Erk was shown to protect from apoptosis and to induce VEGF expression [40,41], our results suggest that a decreased activation of the IGF-1/IGF-1Raxis due to L.obtusiloba extract treatment contributes to its apoptosis-inducing effects and might be a reason for the reduced expression of VEGF and HIF-1 $\alpha$ in HCC cells treated with L.obtusiloba extract [11,12]. These findings are in accordance with studies using extracts from green tea describing a decreased expression of

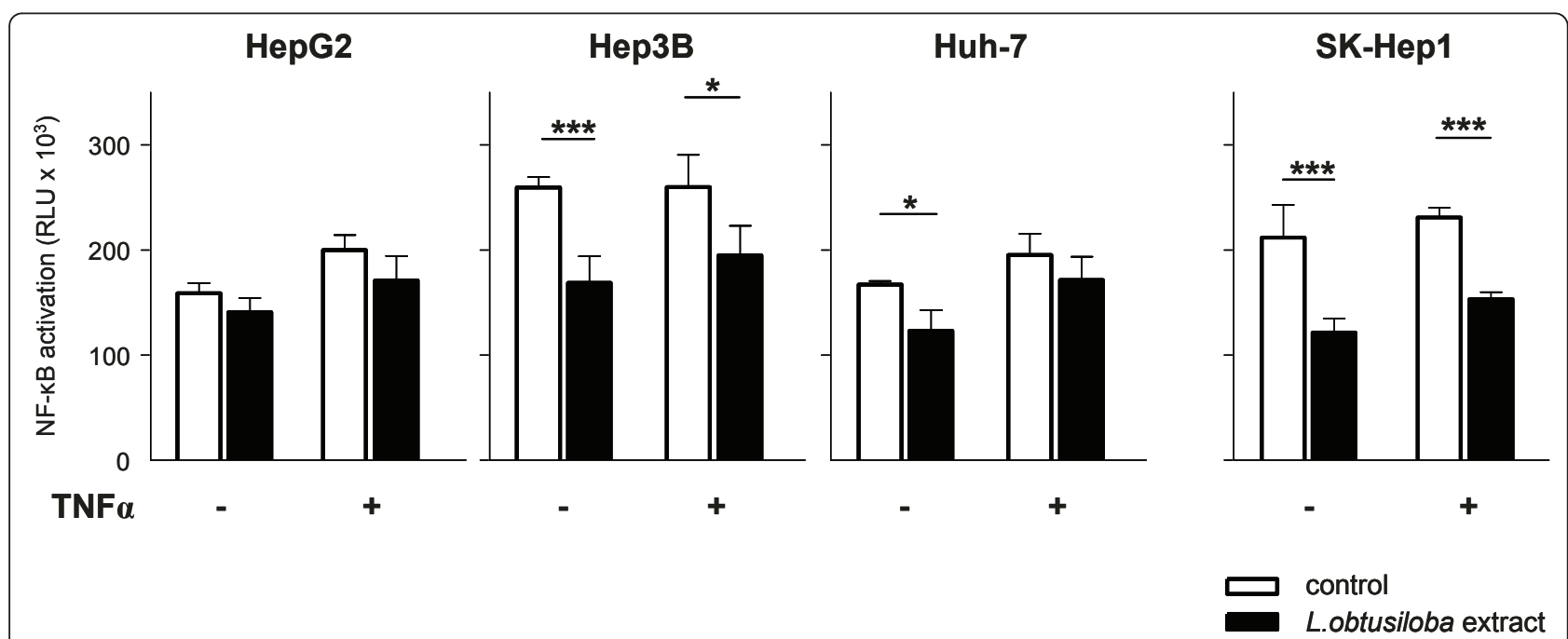

Figure $3 \mathrm{NF}-\kappa \mathrm{B}$ activity of HCC cell lines in the presence of L.obtusiloba extract. HCC cell lines were transfected with a NF- $\kappa \mathrm{B} / \mathrm{luciferase}$ reporter plasmid and allowed to adhere for $20 \mathrm{~h}$ before being treated with $10 \mu \mathrm{g} / \mathrm{ml} \mathrm{TNF} \alpha, 100 \mu \mathrm{g} / \mathrm{ml}$ L.obtusiloba extract or a combination of both. Untreated cells served as negative controls. After additional $24 \mathrm{~h}$, cells were lysed and luciferase activity was determined. Shown are the mean values $\pm \mathrm{SD}$ of four parallel measurements. ${ }^{*} \mathrm{P}<0.05,{ }^{* * *} \mathrm{P}<0.001$. 
VEGF and HIF-1 $\alpha$ accompanied by a block of PI3K/ Akt-signaling in HCC cells [42].

IGF-1R signaling also impacts the expression of the transcription factor PPAR $\gamma$ which in turn modulates the expression of other angiogenesis-regulating proteins like COX-2 and iNOS. The implication of PPAR $\gamma$ in carcinogenesis is still debated. Some data show anti-tumor effects of PPAR $\gamma$ ligands. However, these effects could also be independent of PPAR $\gamma$ activation and in addition the usage of PPAR $\gamma$ antagonists also exerts anticancer effects [43]. In contrast to PPAR $\gamma$, several studies clearly show a positive correlation between the expression of COX-2 and iNOS and HCC progression, e.g. indicated as enhanced microvessel density in HCC [44]. While COX-2 impacts growth and progression of $\mathrm{HCC}$ and its inhibition suppressed HCC-associated angiogenesis in vitro and in vivo [45], iNOS is a key enzyme in generating nitric oxide, thus modulating tumorigenesis by regulating tumor cell proliferation, survival and migration, as well as angiogenesis, drug resistance and DNA repair $[5,46]$.

In line with previous reports $[47,48]$, L.obtusiloba extract reduced the expression of COX-2 and iNOS (Table 2). Notably, poorly differentiated SK-Hep1 cells were susceptible to IGF-1 and inhibition of IGF-1 by $L$. obtusiloba extract. A similar result was obtained for the expression of PPAR $\gamma$ (Table 2). We therefore conclude that downregulation of COX 2 and iNOS by L.obtusiloba extract is mediated by diminished expression of $\operatorname{PPAR} \gamma$.

Beside PPAR $\gamma$, IGF-R-signaling, through different upstream pathways, could trigger the activation of the transcription factor NF- $\kappa \mathrm{B}$ [49] which likewise regulates COX-2 and iNOS and plays a role in viral hepatitis, chronic liver disease including fibrosis and cirrhosis and in HCC $[24,50]$ and is spontaneously activated in HCC cells [22]. Inhibition of NF- $\kappa \mathrm{B}$ reduced proliferation and invasion as well as expression of VEGF in HCC cells and sensitized the cells to sorafenib induced cell death [51].

As shown in Figure 3, L.obtusiloba extract markedly reduced the transcriptional activity of NF- $\kappa \mathrm{B}$ in Hep3B, Huh-7 and SK-Hep1 cells and to a lesser extent in HepG2 cells. Thus, downregulation of COX-2 and iNOS by L.obtusiloba extract is mediated by diminished expression of PPAR $\gamma$ and due to a reduced transcriptional activity of NF- $\kappa$ B. Since NF- $\kappa$ B activity supports cell survival or entails anti-apoptotic effects [23,24,49], the inhibition of NF- $\kappa \mathrm{B}$ by L.obtusiloba extract might contribute to the apoptosis inducing effects of the extract in the cancer cells (Figure 1B).

In summary, our findings in vitro strongly suggest $L$. obtusiloba extract as a specific compound to suppress tumor cell growth and migration and to induce apoptosis in aggressive, poorly differentiated human tumor cells via attenuation of NF- $\kappa \mathrm{B}$ transcriptional activity and IGF-1R signaling. Further, the expression of key proteins in regulation of angiogenesis was reduced due to L.obtusiloba extract treatment. Due to its good physiological compatibility, in Korea L.obtusiloba extract is traditionally applied in humans to treat chronic inflammatory diseases of the liver [28]. Thus, our in vitro results are in line with and add more scientific strength to the traditional use of L.obtusiloba extract in treatment for chronic liver disease including HCC.

Regarding biologically active compounds in the extract several studies describe the isolation and structural characterization of drugs from Lindera obtusiloba [29,30,52]. In this line, preliminary data of us suggest that lignans such as sesamin or episesamin might contribute to the anti-fibrotic and anti-tumor effects of L.obtusiloba extract (not shown).

Complemental to the anti-fibrogenic, anti-inflammatory and anti-adipogenic efficacy of L.obtusiloba extract $[31,32]$, our results suggest the use of an inflammationassociated tumor model of HCC to assess all aspects of the anti-tumor effects of L.obtusiloba extract in vivo.

\section{Conclusions}

Due to its potential to inhibit critical receptor tyrosine kinases involved in HCC progression via the IGF-1 signaling pathway and NF- $\kappa \mathrm{B}$, we conclude that L.obtusiloba extract or its active compounds represent a useful tool in a rational complementary approach e.g. with sorafenib for treatment of $\mathrm{HCC}$ or as cancer preventive agents.

\section{Acknowledgements}

This study was supported by the Collaborative Research Centers (SFB366 C5/ C10) and (SFB633 Z1) from the Deutsche Forschungsgemeinschaft, and by the Medical Research Council, UK.

\section{Author details}

'Department of Gastroenterology, Infectiology and Rheumatology, Charité Universitätsmedizin Berlin, Campus Benjamin Franklin, Hindenburgdamm 30, 12203 Berlin, Germany. ${ }^{2}$ Department of General, Visceral and Transplantation Surgery, Charité - Universitätsmedizin Berlin, Campus Virchow Klinikum, Augustenburger Platz 1, 13353Berlin, Germany. ${ }^{3}$ Department of Surgery, University Hospital Aachen, Pauwelstraße 30, 52074 Aachen, Germany. ${ }^{4}$ Faculty of Beauty Design, Human Environmental Science College, Wonkwang University, Iksan City, South Korea. ${ }^{5}$ Department of Chemical and Pharmaceutical Engineering, Beuth Hochschule für Technik, Luxemburger Str. 10, 13353 Berlin, Germany.

\section{Authors' contributions}

CF participated in the design and coordination of the study, carried out the analyses and wrote the manuscript. MR and UE helped to draft the manuscript. UN and DS provided the HCC cell lines and helped to draft the manuscript. KK helped to prepare the L.obtusiloba extract and helped to draft the manuscript. WTK helped to prepare the L.obtusiloba extract and participated in the design of the study. TS designed the cell transfection experiments. MZ helped to draft the manuscript. RS participated in the data interpretation and manuscript preparation. All authors read and approved the final manuscript. 


\section{Competing interests}

The authors declare that they have no competing interests.

Received: 24 January 2011 Accepted: 12 May 2011

Published: 12 May 2011

\section{References}

1. El-Serag HB, Rudolph KL: Hepatocellular carcinoma: epidemiology and molecular carcinogenesis. Gastroenterology 2007, 132:2557-2576.

2. Villanueva A, Newell P, Chiang DY, Friedman SL, Llovet JM: Genomics and signaling pathways in hepatocellular carcinoma. Semin Liver Dis 2007, 27:55-76.

3. Cheng AL, Kang YK, Chen Z, Tsao CJ, Qin S, Kim JS, Luo R, Feng J, Ye S, Yang TS, et al: Efficacy and safety of sorafenib in patients in the AsiaPacific region with advanced hepatocellular carcinoma: a phase III randomised, double-blind, placebo-controlled trial. Lancet Oncol 2009, 10:25-34.

4. Llovet JM, Ricci S, Mazzaferro V, Hilgard P, Gane E, Blanc JF, de Oliveira AC, Santoro A, Raoul JL, Forner A, et al: Sorafenib in advanced hepatocellular carcinoma. N Engl J Med 2008, 359:378-390.

5. Lasagna N, Fantappie O, Solazzo M, Morbidelli L, Marchetti S, Cipriani G, Ziche M, Mazzanti R: Hepatocyte growth factor and inducible nitric oxide synthase are involved in multidrug resistance-induced angiogenesis in hepatocellular carcinoma cell lines. Cancer Res 2006, 66:2673-2682.

6. Jones $\mathrm{Jl}$, Clemmons DR: Insulin-like growth factors and their binding proteins: biological actions. Endocr Rev 1995, 16:3-34.

7. Zender L, Villanueva A, Tovar V, Sia D, Chiang DY, Llovet JM: Cancer gene discovery in hepatocellular carcinoma. J Hepatol 2010, 2010:20.

8. Khandwala HM, McCutcheon IE, Flyvbjerg A, Friend KE: The effects of insulin-like growth factors on tumorigenesis and neoplastic growth. Endocr Rev 2000, 21:215-244.

9. Pollak MN, Schernhammer ES, Hankinson SE: Insulin-like growth factors and neoplasia. Nat Rev Cancer 2004, 4:505-518.

10. Alexia C, Fallot G, Lasfer M, Schweizer-Groyer G, Groyer A: An evaluation of the role of insulin-like growth factors (IGF) and of type-I IGF receptor signalling in hepatocarcinogenesis and in the resistance of hepatocarcinoma cells against drug-induced apoptosis. Biochem Pharmacol 2004, 68:1003-1015.

11. Parrizas M, Saltiel AR, LeRoith D: Insulin-like growth factor 1 inhibits apoptosis using the phosphatidylinositol 3 '-kinase and mitogenactivated protein kinase pathways. J Biol Chem 1997, 272:154-161.

12. Peruzzi F, Prisco M, Dews M, Salomoni P, Grassilli E, Romano G, Calabretta B, Baserga R: Multiple signaling pathways of the insulin-like growth factor 1 receptor in protection from apoptosis. Mol Cell Biol 1999, 19:7203-7215.

13. Fukuda R, Hirota $K$, Fan F, Jung $Y D$, Ellis $L M$, Semenza GL: Insulin-like growth factor 1 induces hypoxia-inducible factor 1-mediated vascular endothelial growth factor expression, which is dependent on MAP kinase and phosphatidylinositol 3-kinase signaling in colon cancer cells. J Biol Chem 2002, 277:38205-38211, Epub 32002 Jul 38230.

14. Nakamura K, Zen Y, Sato Y, Kozaka K, Matsui O, Harada K, Nakanuma Y: Vascular endothelial growth factor, its receptor Flk-1, and hypoxia inducible factor-1alpha are involved in malignant transformation in dysplastic nodules of the liver. Hum Pathol 2007, 38:1532-1546, Epub 2007 Jul 1519.

15. Torimura T, Sata M, Ueno T, Kin M, Tsuji R, Suzaku K, Hashimoto O, Sugawara $H$, Tanikawa K: Increased expression of vascular endothelial growth factor is associated with tumor progression in hepatocellular carcinoma. Hum Pathol 1998, 29:986-991.

16. Samani AA, Yakar S, LeRoith D, Brodt P: The role of the IGF system in cancer growth and metastasis: overview and recent insights. Endocr Rev 2007, 28:20-47, Epub 2006 Aug 2024.

17. De Meyts P, Whittaker J: Structural biology of insulin and IGF1 receptors: implications for drug design. Nat Rev Drug Discov 2002, 1:769-783.

18. Tovar V, Alsinet C, Villanueva A, Hoshida Y, Chiang DY, Sole M, Thung S, Moyano S, Toffanin S, Minguez B, et al: IGF activation in a molecular subclass of hepatocellular carcinoma and pre-clinical efficacy of IGF-1R blockage. J 2010, 52:550-559.

19. Higano C, Yu E, Whiting S, Gordon M, LoRusso P, Fox F: A phase I, first in man study of weekly IMC-A12, a fully human insulin like growth factor 1 receptor IgG1 monoclonal antibody, in patients with advanced solid tumors. J Clin Oncol 2007, 25(Suppl 18):3505, [abstract].
20. Salminen A, Kaarniranta K: Insulin/IGF-1 paradox of aging: regulation via AKT/IKK/NF-kappaB signaling. Cell Signal 2010, 22:573-577.

21. Naugler WE, Karin M: NF-kappaB and cancer-identifying targets and mechanisms. Curr Opin Genet Dev 2008, 18:19-26, Epub 2008 Apr 2024.

22. Liu TZ, Hu CC, Chen YH, Stern A, Cheng JT: Differentiation status modulates transcription factor NF-kappaB activity in unstimulated human hepatocellular carcinoma cell lines. Cancer Lett 2000, 151:49-56.

23. Dalwadi H, Krysan K, Heuze-Vourc'h N, Dohadwala M, Elashoff D, Sharma S, Cacalano N, Lichtenstein A, Dubinett S: Cyclooxygenase-2-dependent activation of signal transducer and activator of transcription 3 by interleukin-6 in non-small cell lung cancer. Clin Cancer Res 2005, 11:7674-7682.

24. Calvisi DF, Pinna F, Ladu S, Pellegrino R, Muroni MR, Simile MM, Frau M, Tomasi ML, De Miglio MR, Seddaiu MA, et al: Aberrant iNOS signaling is under genetic control in rodent liver cancer and potentially prognostic for the human disease. Carcinogenesis 2008, 29:1639-1647, Epub 2008 Jun 1625 .

25. Khan N, Mukhtar $\mathrm{H}$ : Multitargeted therapy of cancer by green tea polyphenols. Cancer Lett 2008, 269:269-280, Epub 2008 May 2022.

26. Stickel F, Brinkhaus B, Krahmer N, Seitz HK, Hahn EG, Schuppan D: Antifibrotic properties of botanicals in chronic liver disease. Hepatogastroenterology 2002, 49:1102-1108.

27. Lee JH, Jin H, Shim HE, Kim HN, Ha H, Lee ZH: Epigallocatechin-3-gallate inhibits osteoclastogenesis by down-regulating c-Fos expression and suppressing the NF-\{kappa\}B signal. Mol Pharmacol 2009, 14:14.

28. Yook C: Lindera obtusiloba. Medical Plants of Korea Seoul: Jinmyeong Publishing Co: 1989, 184

29. Kwon HC, Baek NI, Choi SU, Lee KR: New cytotoxic butanolides from Lindera obtusiloba BLUME. Chem Pharm Bull (Tokyo) 2000, 48:614-616.

30. Kwon HC, Choi SU, Lee JO, Bae KH, Zee OP, Lee KR: Two new lignans from Lindera obtusiloba blume. Arch Pharm Res 1999, 22:417-422.

31. Ruehl M, Erben U, Kim K, Freise C, Dagdelen T, Eisele S, TrowitzschKienast W, Zeitz M, Jia J, Stickel F, Somasundaram R: Extracts of Lindera obtusiloba induce antifibrotic effects in hepatic stellate cells via suppression of a TGF-beta-mediated profibrotic gene expression pattern. J Nutr Biochem 2009, 20:597-606, Epub 2008 Sep 2027.

32. Freise C, Erben U, Kim K, Zeitz M, Somasundaram R, Ruehl M: An active extract of Lindera obtusiloba inhibits adipogenesis via sustained Wnt signaling and exerts anti inflammatory effects in the 3T3-L1 preadipocytes. J Nutr Biochem 2010, 12:1170-1177, Epub 2010 Jan 25.

33. Stroh T, Batra A, Glauben R, Fedke I, Erben U, Kroesen A, Heimesaat MM, Bereswill S, Girardin S, Zeitz M, Siegmund B: Nucleotide oligomerization domains 1 and 2: regulation of expression and function in preadipocytes. J Immunol 2008, 181:3620-3627.

34. Stroh T, Erben U, Kuhl AA, Zeitz M, Siegmund B: Combined pulse electroporation-a novel strategy for highly efficient transfection of human and mouse cells. PLoS 2010, 5:e9488.

35. Okun I, Balakin KV, Tkachenko SE, Ivachtchenko AV: Caspase activity modulators as anticancer agents. Anticancer Agents Med Chem 2008, 8:322-341

36. Kaur G, Hollingshead M, Holbeck S, Schauer-Vukasinovic V, Camalier RF, Domling A, Agarwal S: Biological evaluation of tubulysin A: a potential anticancer and antiangiogenic natural product. Biochem J 2006, 396:235-242.

37. Greten TF, Korangy F, Manns MP, Malek NP: Molecular therapy for the treatment of hepatocellular carcinoma. Br J Cancer 2009, 100:19-23, Epub 2008 Nov 2018.

38. Shimizu M, Shirakami Y, Sakai H, Tatebe H, Nakagawa T, Hara Y, Weinstein IB, Moriwaki H: EGCG inhibits activation of the insulin-like growth factor (IGF)//GF-1 receptor axis in human hepatocellular carcinoma cells. Cancer Lett 2007, 28:28.

39. Pang R, Poon RT: Angiogenesis and antiangiogenic therapy in hepatocellular carcinoma. Cancer Lett 2006, 242:151-167, Epub 2006 Mar 2027.

40. Mitsiades CS, Mitsiades N, Koutsilieris M: The Akt pathway: molecular targets for anti-cancer drug development. Curr Cancer Drug Targets 2004, 4:235-256.

41. Xu Q, Briggs J, Park S, Niu G, Kortylewski M, Zhang S, Gritsko T, Turkson J, Kay H, Semenza GL, et al: Targeting Stat3 blocks both HIF-1 and VEGF expression induced by multiple oncogenic growth signaling pathways. Oncogene 2005, 24:5552-5560. 
42. Zhang Q, Tang X, Lu Q, Zhang Z, Rao J, Le AD: Green tea extract and (-)-epigallocatechin-3-gallate inhibit hypoxia- and serum-induced HIF1alpha protein accumulation and VEGF expression in human cervical carcinoma and hepatoma cells. Mol Cancer Ther 2006, 5:1227-1238.

43. Borbath I, Horsmans Y: The Role of PPARY in Hepatocellular Carcinoma. PPAR Research 2008.

44. Rahman MA, Dhar DK, Yamaguchi E, Maruyama S, Sato T, Hayashi H, Ono T, Yamanoi A, Kohno H, Nagasue N: Coexpression of inducible nitric oxide synthase and COX-2 in hepatocellular carcinoma and surrounding liver: possible involvement of COX-2 in the angiogenesis of hepatitis C viruspositive cases. Clin Cancer Res 2001, 7:1325-1332.

45. Wu T: Cyclooxygenase-2 in hepatocellular carcinoma. Cancer Treat Rev 2006, 32:28-44, Epub 2005 Dec 2007.

46. Hussain SP, Harris CC: Inflammation and cancer: an ancient link with novel potentials. Int J Cancer 2007, 121:2373-2380

47. Nagahara T, Okano J, Murawaki Y: Mechanisms of anti-proliferative effect of JTE-522, a selective cyclooxygenase-2 inhibitor, on human liver cancer cells. Oncol Rep 2007, 18:1281-1290.

48. Glinghammar B, Skogsberg J, Hamsten A, Ehrenborg E: PPARdelta activation induces COX-2 gene expression and cell proliferation in human hepatocellular carcinoma cells. Biochem Biophys Res Commun 2003, 308:361-368.

49. Salminen A, Kaarniranta K: Insulin/IGF-1 paradox of aging: regulation via AKT/IKK/NF-kappaB signaling. Cell Signal 2009, 22:573-577.

50. Sun B, Karin M: NF-kappaB signaling, liver disease and hepatoprotective agents. Oncogene 2008, 27:6228-6244.

51. Wu JM, Sheng H, Saxena R, Skill NJ, Bhat-Nakshatri P, Yu M, Nakshatri $H$ Maluccio MA: NF-kappaB inhibition in human hepatocellular carcinoma and its potential as adjunct to sorafenib based therapy. Cancer Lett 2009, 278:145-155, Epub 2009 Mar 2020.

52. Lee KY, Kim SH, Jeong EJ, Park JH, Kim YC, Sung SH: New secoisolariciresinol derivatives from Lindera obtusiloba stems and their neuroprotective activities. Planta Med 2009, 76:294-297.

\section{Pre-publication history}

The pre-publication history for this paper can be accessed here: http://www.biomedcentral.com/1472-6882/11/39/prepub

doi:10.1186/1472-6882-11-39

Cite this article as: Freise et al: A hepatoprotective Lindera obtusiloba extract suppresses growth and attenuates insulin like growth factor-1 receptor signaling and NF-kappaB activity in human liver cancer cell lines. BMC Complementary and Alternative Medicine 2011 11:39.

\section{Submit your next manuscript to BioMed Central and take full advantage of:}

- Convenient online submission

- Thorough peer review

- No space constraints or color figure charges

- Immediate publication on acceptance

- Inclusion in PubMed, CAS, Scopus and Google Scholar

- Research which is freely available for redistribution

Submit your manuscript at www.biomedcentral.com/submit
Biomed Central 